\title{
GROWTH-INHIBITORY EFFECT OF SOME ANTI- NUTRITIONAL FACTORS EXTRACTED FROM ACACIA SALIGNA LEAVES ON INTESTINAL BACTERIA ACTIVITY IN SHEEP
}

\author{
A.Z.M. Salem ${ }^{1}$, Y.M.Gohar ${ }^{2}$, M.M.El-Adawy ${ }^{1}$ and M.Z.M.Salem ${ }^{3}$ \\ 1- Department of Animal Production, Faculty of Agriculture (El-Shatby), Alexandria \\ University, Alexandria, Egypt, 2- Division of Microbiology, Faculty of Science, \\ Alexandria University, Alexandria, Egypt, 3- Department of Timber Trees and Wood \\ Technology, Faculty of Agriculture (El-Shatby), Alexandria University, Egypt
}

\section{SUMMARY}

This work was conducted to evaluate the inhibitory effect of some anti-nutritional factors (ANFs) extracted from Acacia saligna leaves on lactic acid intestinal bacteria (LAIB) activity. Two LAIB strains (Lactobacillus planterum-2LMB and Enterococcus faecium-1LMB) were isolated from Barki sheep feces by repeated plating on MRS and M17 agar medium to select the pure colonies of Lactobacillus sp. and Enteroccocus sp. respectively. SDS-PAGE Gel Electrophoresis and API 50 (Analytical Profile Index) were used to identify the strains. Methanolic extract, phenolic components, saponins, alkaloids, and aqueous fraction were extracted from the leaves. The inhibitory effect of each one of extracted ANFs was tested at the level of 20000 ppm on L. planterum, E. faecium, and their mixture (L. planterum $+E$. faecium by 1:1). Higher toxicity (using disc diffusion assay) was observed with phenolic components (on L. planterum and L. planterum + E. faecium) and methanolic extract (on E. faecium). Number of mutant colonies was higher $(P<0.001)$ under phenolic components (on L. planterum), aqueous fraction (on E. faecium) and methanolic extract (L. planterum + E. faecium) than other ANFs. Higher inhibitory effect $(P<0.001)$ on bacterial growth $\left(O D_{600}\right)$, lactic acid and biomass production by L. planterum and L. planterum + E. faecium was registered under phenolic components, and under methanolic extract by E. faecium. Mixing $L A I B$ under all ANFs reduced toxicity, increased mutant colonies, improved bacterial growth, lactic acid and biomass production as a consequence to the capacity of LAIB to tolerate the negative effect of the different ANFs extracted from Acacia saligna leaves. In conclusion, phenolic components are the major group of ANFs in Acacia saligna leaves, which had more inhibitory effect than other ANFs on LAIB activity. Lactobacilli sp. had a higher susceptibility than Enterococci sp. to the ANFs. Mixing $L A I B$ had increased their tolerance to all ANFS.

Keywords: Acacia saligna, anti-nutritional factors, toxicity, L. planterum, E. faecium, lactic acid, sheep

\section{INTRODUCTION}

Plants have an almost limitless ability to synthesize aromatic substances, most of which are phenols or their oxygen-substituted derivatives (Geissman, 1963). Most are secondary metabolites, of which at least 12,000 have been isolated, a number 
estimated to be less than $10 \%$ of the total (Schultes, 1978). In many cases, these substances serve as plant defense mechanisms against predation by microorganisms, insects, and herbivores. Some, such as terpenoids, give plants their odors; others (quinones and tannins) are responsible for plant pigment. Many compounds are responsible for plant flavor (e.g., the terpenoid capsaicin from chili peppers).

Browse species such as Acacia saligna play a major role in providing feed for ruminants in arid and sami-arid regions (Kibon and Ørskov, 1993; Ahn et al., 1989). Many browse species are associated with deleterious effects on livestock via the aniti-nutritional factors that could affect negatively on animal performance. Most of these aniti-nutritional factors are aromatic components, which include phenolics components (tannins and their derivatives), quinines, flavonoids, terpenoids, essential oils, coumarins, alkaloids, lactins and polypeptides (Cowan, 1999). These components are considered as anti-microbial agents against several microorganisms Berkada, (1978); Avorn, (1996); Freiburghaus et al. (1996); Martinez et al. (1996) and McDevitt et al. (1996). Little attention has been given to natural plat extracts as a possible toxic effect on intestinal bacteria in ruminant animals (Cowan, 1999).

The aim of our present research work was conducted to evaluate the inhibitory effect of some anti-nutritional factors extracted from Acacia saligna leaves on lactic acid intestinal bacteria activity in sheep.

\section{MATERIALS AND METHODS}

\section{Isolation, identified and culture medium of Lactic Acid Intestinal Bacteria (LAIB)} from healthy Barki sheep

The isolation and identification of the LAIB was carried out by the same methods which was previously described by Salem et al., (2004).

Three healthy, adults females Barki sheep housed in the farm of the Department of Animal Production, Faculty of Agriculture, Alexandria University was selected to supply fecal samples for the isolation of LAIB. One gram of each fecal sample was added to $10 \mathrm{ml}$ of sterile De Man et al.(1960) (MRS) broth media (composition in g/liter: 10.0 universal peptone; 5.0 yeast extract; $20.0 \mathrm{D}(+)$ glucose; 2.0 di-potassium hydrogen phosphate; 1.0 polyoxyethylene sorbitan monooleate; 2.0 di-ammonium hydrogen citrate; 5.0 sodium acetate; 0.1 magnesium sulfate; 12.0 agar-agar "not present in MRS broth") for cultivation and enumeration of Lactobacillus sp. Another one gram of fecal sample was added to $10 \mathrm{ml}$ of M17 broth medium (composition in g/liter: 5.0 peptone from soymeal; 2.5 peptone from meat; 2.5 peptone from casein; 2.5 yeast extract; 5.0 meat extract; $5.0 \mathrm{D}(+)$ lactose; 5.0 ascorbic acid; 19.0 sodium $\beta$ glycerophosphate; 0.25 magnesium sulfate; 12.75 agar-agar "not present in M17 broth") for cultivation and enumeration of Enteroccocus sp. this media was proposed by Terzaghi and Sandine (1975). All samples were then mixed thoroughly. The fecal material was then streaked onto MRS and M17 agar plates for Lactobacillus sp. and Enteroccocus $s p$. selection, respectively. The plates were incubated at $37^{\circ} \mathrm{C}$ for $48 \mathrm{~h}$ in plastic bags flushed with $\mathrm{CO}_{2}$ for $30 \mathrm{~s}$. Approximately 10 to 15 well-isolated colonies were picked up from each plate and transferred to individual tubes containing $10 \mathrm{ml}$ of MRS or M17 broth medium, which were further incubated at 37 ${ }^{\circ} \mathrm{C}$ for 18 to $72 \mathrm{~h}$ to obtain maximum growth of the cultures. The isolated cultures were re-streaked onto MRS or M17 agar plates for Lactobacillus sp. and Enteroccocus sp. selection and incubated at $37^{\circ} \mathrm{C}$ for $48 \mathrm{~h}$ until isolated colonies of 
one form were obtained. Pure colonies were Gram stained for preliminary identification. The isolated cultures were maintained at frozen $\left(-70^{\circ} \mathrm{C}\right)$ stocks in MRS broth supplemented with $10 \%$ (vol/vol) sterile glycerol. Isolates were sub-cultured in MRS or M17 broth medium at $37^{\circ} \mathrm{C}$ for 24 to $48 \mathrm{~h}$ (culture activation) before they were used for further studies.

Lactobacillus planterum-2LMB and Enterococcus faecium-1LMB were identified by morphologically and physiological testes (Hardie, 1968: Sharpe, 1979; Garvie, 1986; Kandler and Weiss, 1986). Gram-positive cocci (Enterococcus faecium1LMB) were tested for growth in M17 broth medium. Gram-positive rod shaped isolate (Lactobacillus planterum-2LMB) was tested for growth in MRS broth and also $\mathrm{CO}_{2}$ production. The identification was completed by sugar fermentation patterns obtained with the API 50 galleries (bio Merieux, Vercieu, France); results were analyzed by computerized database software provided by the manufacturer. The identity of LAIB isolates was confirmed by the SDS-PAGE (sodium dodecyle sulfate) technique of whole-cell proteins as described by Pot et al., (1994) and Ausubel et al., (1995). The purity of the isolated bacteria was evaluated by Tricinesodium dodecyle sulfate (SDS)-polyacrylamide gel electrophoresis. Gels $(10 \%$ acrylamide) were silver stained for visualization of peptides. Bands patterns of isolates were scanned. Normalized and compared to database of normalized protein fingerprints of LAIB reference strains by use of Gel compare 4.0 software (Applied Maths, Kortrijk, Belgium) which was also used for generation of cluster analysis.

\section{Treatments}

Three LAIB (L. planterum, E. faecium, and their mixture (L. planterum + E. faecium by 1:1) were tested by each one of the following anti-nutritional factors (ANFs) extracted from A. saligna leaves at the level 20000 ppm: Methanolic extract; Phenolic components; Saponins; Alkaloids; Aqueous fraction (lactins, polypeptides and starch, Cowan, 1999). Bacterial strains (L. planterum, E. faecium, and their mixture) were activated by their incubation at $37^{\circ} \mathrm{C}$ for 24 and their turbidity was adjusted to $O D_{600}=1$ with sterilized broth medium before used in the inoculation experiments.

\section{Extraction of ANFs}

A. saligna leaves were collected during April, May, and June, 2003 and sourced from the experimental station of the Faculty of Agriculture, Alexandria University.

For the methanol extract, plant materials were dried in the shade, reduced to small pieces and then homogenized using a blender. Powdered plant (150g) was extracted with $80 \%$ methanol and evaporated under reduced pressure at $40^{\circ} \mathrm{C}$. The extract was dried overnight (lyophilized) in vacuum desiccators and stored in the freezer until used. For the phenolic components, a part of the methanol extract was fractionated with a mixture of methanol and ethanol (Hussein et la., 1999). For the alkaloid extract, dried samples were firstly extracted with ethanol and dissolved in diluted $\mathrm{HCl}$. this solution was filtrated and extracted with petrol to remove fats (Arambewela and Ranatunge, 1991). Saponins were extracted and isolated according to the method of Ahmed et al., (1990). Dried samples were extracted with methanol several times. The combined methanolic extract was evaporated and partitioned 
between ethanol acetate and $\mathrm{H}_{2} \mathrm{O}$. Aqueous fraction (AF) was determined according to the method of Hussein et al., (1999) using the fractionation by column chromatography of extracted samples by saturated the extract with $\mathrm{H}_{2} \mathrm{O}$ and $50 \%$ methanol.

\section{Inhibitory effect of ANFs on LAIB}

Toxicity effect of each one of ANFs on the two identified strains (L. planterum and E. faecium) and their mixtures was determined by disc diffusion assay (Thornberry, 1950). Filter paper discs (Watman No. 1, 3-mm diameter) were impregnated with $10 \mu \mathrm{l}$ of each one of the ANFs. Discs were applied to the surface of agar plates that were previously inculated with activated culture of LAIB strains. The plates were flushed with $\mathrm{CO}_{2}$ for $30 \mathrm{sec}$. and incubated at $37^{\circ} \mathrm{C}$. The area of inhibition zone $\left(\mathrm{mm}^{2}\right)$ formulated around each disc was recorded after $72 \mathrm{~h}$. Determination of inhibition zone of each one of the previous ANFs on the growth of LAIB strains was replicated three times.

\section{LAIB growth}

Growth of LAIB in presence of ANFs was measured turbidimeterically as change in optical density $(O D)$ at $600 \mathrm{~nm}$ (Spectronic spectrophotometer 20D ${ }^{+}$, Laboratory of Animal Nutrition, Faculty of Agriculture, Alexandria University). Aliquots of culture fluid were taken at regular intervals during growth (after 3, 6, 24, 48 and $72 \mathrm{~h}$ of incubation) for measurements of $O D_{600}$ and lactic acid concentration. All measurements were carried out under sterilized and anaerobic conditions. Determinations were replicated three times for each sample.

\section{Lactic acid assay}

A simple colorimetric assay was used to determine lactic acid concentration proposed by Taylor (1996) in intestinal bacteria medium of lower gut in ruminant's animals. For a standard curve, it was added $0-30 \mu \mathrm{g}$ lactic acid to $16 \mathrm{X} 150-\mathrm{mm}$ borosilicate tubes. The curve should be in $5-\mu \mathrm{g}$ increments or less. This volume was transfered in tubes up to $0.5 \mathrm{ml}$ with double distilld water. Three millitre of concentrated $\mathrm{H}_{2} \mathrm{SO}_{4}$ were added and mixed on a vortex mixer. The quantity of acid was difined here as $82 \%$ acid. Samples were incubated at $95-100^{\circ} \mathrm{C}$ for $10 \mathrm{~min}$ (in a steam water bath). Extraneous water was kept out of the tube and then they were cooled under room tempreture. $\mathrm{CuSO}_{4}$ reagent was added and then $100 \mu \mathrm{L}$ of $p$ phenylphenol reagent. The mixture was mixed well in a vortex mixer and tubes were left at room temprature for at least $30 \mathrm{~min}$ and then the absorbance was read at 570 $\mathrm{nm}$ (Spectronic spectrophotometer 20D ${ }^{+}$). Blanks were showed values of $0.2-0.5$ compared with water. One sample of medium growth during the time of incubation (after 3, 6, 24, 48 and $72 \mathrm{~h}$ of incubation) was taken to determine lactic acid production.

\section{Biomass assay}

After $72 \mathrm{~h}$ of incubation, the cell dry weight $\left(\mathrm{g} \mathrm{L}^{-1}\right)$ or biomass production of each one of LAIB samples and their previous mixtures used was determined. The rest volume of growth medium after the $72 \mathrm{~h}$ of incubation was harvested and centrifuged (Heraeus Christ GmbH, Model Osrterode/Harz-Cryofuge 20-3) at $4000 \mathrm{X}$ g for 10 min at $4^{\circ} \mathrm{C}$. The obtaind pellet was washed twice with quarter strength of Ringers 
solution (compositon in $\mathrm{g} / \mathrm{L}$ : 2.25 sodium chlorid; 0.105 potassium chlorid; 0.12 calcium chlorid; 0.05 sodium bicarbonate). The washed pellet in the centrifuge cups was then dried at $105^{\circ} \mathrm{C}$ for $4 \mathrm{~h}$ to a constant weight.

\section{Statistical analysis}

Data were statistically analyzed by ANOVA (Steel and Torrie, 1980) using GLM procedure (SAS, 1993). The relationship between the toxicity and bacterial growth or lactic acid production was investigated using EXCEL program.

\section{RESULTS AND DISCUSSION}

The gastrointestinal tract contains the largest number and most complex population of microorganisms. There are at lest 400 different species of bacteria (Berg, 1996 and Savage, 1977). Anaerobes outnumber aerobes and facultative species by a factor of 100 to 1,000 (Moore et al., 1974). Gut microbes conduct a multitude of biochemical reactions and can be collectively thought of as a metabolically active. This metabolic entity plays a critical role in nutrition, degrading a number of dietary substances that are otherwise nondigestible (Savage, 1989) and also toxic materials. Teleologicaly, this arrangement makes a great deal of sense. By recuting a society of resident microbes with metabolic capabilities that allow them to break down these components, the host is relieved of the need to evolve such functions. The host also achieves a degree of metabolic adaptability that can help it deal with changes in diet and nutrient availability.

Table 1. Effect of different anti-nutritional factors extracted from Acacia saligna leaves on the toxicity ${ }^{\#}$ of isolated lactic acid intestinal bacteria in sheep

\begin{tabular}{llllll}
\hline & \multicolumn{4}{c}{ Bacterial strain } & \\
\cline { 2 - 4 } Treatment & LP & EF & LP + EF & $\operatorname{Sed}_{\mathrm{B}(\mathrm{A})}$ & Sig \\
\hline Methanolic extract & $15.44^{\mathrm{B}}$ & $14.78^{\mathrm{A}}$ & $9.40^{\mathrm{AB}}$ & 3.024 & NS \\
Phenolic components & $25.54^{\mathrm{aA}}$ & $10.81^{\mathrm{bAB}}$ & $14.29^{\mathrm{abA}}$ & 4.815 & $*$ \\
Saponins & $15.69^{\mathrm{aB}}$ & $7.35^{\mathrm{bBC}}$ & $8.61^{\mathrm{bAB}}$ & 2.616 & $*$ \\
Alkaloids & $6.86^{\mathrm{B}}$ & $8.61^{\mathrm{BC}}$ & $5.47^{\mathrm{B}}$ & 1.619 & NS \\
Aqueous fraction & $12.81^{\mathrm{aB}}$ & $5.08^{\mathrm{bC}}$ & $6.41^{\mathrm{bB}}$ & 1.714 & $* *$ \\
Sed & $3.872^{\mathrm{B})}$ & 2.023 & 2.778 & & \\
Sig & $* *$ & $* *$ & $\mathrm{NS}$ & & \\
\hline
\end{tabular}

LP: Lactobacillus planterum, EF: Enterococcus faecium, LP + EF: Lactobacillus planterum + Enterococcus faecium $(1: 1)$. \#: Measured as the inhibition zone area $\left(\mathrm{mm}^{2}\right)$ formulated around discs using disc diffusion assay.

${ }_{A, B, C, D}$ means in the same column with different superscripts are significantly different between treatments within each one of lactic acid intestinal bacteria strains,

$*(\mathrm{P}<0.05) \quad * *(\mathrm{P}<0.01) \quad$ NS: not significance $\quad$ Sig.: Level of significant. ${ }^{\mathrm{a}, \mathrm{b}}$ means in the same row with different superscripts are significantly different between lactic acid intestinal bacteria within each one of treatments.

$\operatorname{Sed}_{\mathrm{A}(\mathrm{B})}$ : stander error of the differences between treatments within each lactic acid intestinal bacteria strains.

$\operatorname{Sed}_{B(A)}$ : stander error of the differences between lactic acid intestinal bacteria strains within each treatments. 
Higher toxicity effect of ANFs was observed by phenolic components on $L$. planterum and L. planterum + E. faecium than E. faecium singly (Table 1 ). The other ANFs had an intermediate toxicity on LAIB. This results were confirmed when it was measured the bacterial growth $\left(O D_{600}\right)$ of each LAIB strains under the different ANFs extracted from $A$. saligna leaves (Table 2 and 3 ). Higher inhibitory effect of $L$. planterum and the mixture of L. planterum + E. faecium $(54.59$ and $36.13 \%$, receptivity) was observed when bacterial strains exposed to the phenolic components. E. faecium had a highly inhibitory effect under the methanolic extract $(24.92 \%)$. Saponins and alkaloids had a higher $(\mathrm{P}<0.05)$ toxicity effect on L. planterum than $E$. faecium and the mixture of tested bacteria regarding to the mechanism of action of highly aromatic planar quaternary alkaloids such as berberine and harmane (Hopp et al., 1976) is attributed to their ability to intercalate with DNA (Phillipson and O' Neill 1987) and the negative effect of saponins (Lu and Jorgensen, 1987). Aqueous fraction reduced $(\mathrm{P}<0.05)$ bacterial growth of $L$. planterum than other bacterial strains. It was reported that, aqueous fraction (peptides and lactins) have an inhibitory effect on microorganisms (Balls, et al., 1942). They are often positively charged and contain disulfide bonds (Zhang and Lewis, 1997). Their mechanism of action may be the formation of ion channels in the microbial membrane (Terras et al., 1993 and Zhang and Lewis, 1997) or competitive inhibition of adhesion of microbial proteins to host polysaccharide receptors (Sharon and Ofek, 1986). Bacterial growth was improved significantly by mixing bacteria except at the case of phenolic components and saponins, bacterial growth was highest at E. faecium than other tested bacterial strains.

Table 2. Effect of different anti-nutritional factors extracted from Acacia saligna leaves on growth $\left(O D_{600}\right)$ of isolated lactic acid intestinal bacteria in sheep

\begin{tabular}{|c|c|c|c|c|c|}
\hline \multirow[b]{2}{*}{ Treatment } & \multicolumn{3}{|c|}{ Bacterial strain } & \multirow[b]{2}{*}{$\operatorname{Sed}_{B(A)}$} & \multirow[b]{2}{*}{ Sig } \\
\hline & LP & $\mathrm{EF}$ & $\mathrm{LP}+\mathrm{EF}$ & & \\
\hline Control & $0.566^{\mathrm{cA}}$ & $0.610^{\mathrm{bA}}$ & $0.714^{\mathrm{aA}}$ & 0.0105 & $* * *$ \\
\hline Methanolic extract & $0.380^{\mathrm{cD}}$ & $0.458^{\mathrm{bF}}$ & $0.523^{\mathrm{aD}}$ & 0.0017 & $* * *$ \\
\hline Phenolic components & $0.257^{\mathrm{cF}}$ & $0.522^{\mathrm{aE}}$ & $0.456^{\mathrm{bE}}$ & 0.0019 & $* * *$ \\
\hline Saponins & $0.372^{\mathrm{cE}}$ & $0.588^{\mathrm{aB}}$ & $0.555^{\mathrm{bC}}$ & 0.0021 & $* * *$ \\
\hline Alkaloids & $0.534^{\mathrm{cB}}$ & $0.566^{\mathrm{bC}}$ & $0.623^{\mathrm{aB}}$ & 0.0018 & $* * *$ \\
\hline Aqueous fraction & $0.424^{\mathrm{cC}}$ & $0.542^{\mathrm{bD}}$ & $0.559^{\mathrm{aC}}$ & 0.0015 & $* * *$ \\
\hline $\operatorname{Sed}_{\mathrm{A}(\mathrm{B})}$ & 0.0026 & 0.0062 & 0.0043 & & \\
\hline Sig & $* * *$ & $* * *$ & $* * *$ & & \\
\hline
\end{tabular}

LP: Lactobacillus planterum, EF: Enterococcus faecium, LP + EF: Lactobacillus planterum + Enterococcus faecium (1:1).

$\mathrm{A}, \mathrm{B}, \mathrm{C}, \mathrm{D}$ means in the same column with different superscripts are significantly different between treatments within each one of lactic acid intestinal bacteria strains.

$* * *(\mathrm{P}<0.001) \quad$ NS: not significance $\quad$ Sig.: Level of significant.

${ }^{\mathrm{a}, \mathrm{b}}$ means in the same row with different superscripts are significantly different between lactic acid intestinal bacteria within each one of treatments.

$\operatorname{Sed}_{\mathrm{A}(\mathrm{B})}$ : stander error of the differences between treatments within each lactic acid intestinal bacteria strains.

$\operatorname{Sed}_{B(A)}$ : stander error of the differences between lactic acid intestinal bacteria strains within each treatments. 
Table 3. Inhibitory effect (\%) of different anti-nutritional factors extracted from Acacia saligna leaves on growth $\left(O D_{600}\right)$ of isolated lactic acid intestinal bacteria in sheep

\begin{tabular}{lccc}
\hline & \multicolumn{3}{c}{ Bacterial strain } \\
\cline { 2 - 4 } Treatment & LP & EF & LP + EF \\
\hline Control & 0.00 & 0.00 & 0.00 \\
Methanolic extract & 32.86 & 24.92 & 26.75 \\
Phenolic components & 54.59 & 14.43 & 36.13 \\
Saponins & 34.28 & 3.61 & 22.27 \\
Alkaloids & 5.65 & 7.21 & 12.75 \\
Aqueous fraction & 25.09 & 11.15 & 12.75 \\
\hline
\end{tabular}

LP: Lactobacillus planterum, EF: Enterococcus faecium, LP + EF: Lactobacillus planterum + Enterococcus faecium (1:1).

This inhibitory effect may be related to the capacity of hydroxylated phenolic components to toxic microorganisms. The site(s) and number of hydroxyl groups on the phenol group are thought to be related to their relative toxicity to microorganisms, with evidence that increased hydroxylation results in increased toxicity (Geissman, 1963). In addition, some authors have found that more highly oxidized phenols are more inhibitory (Urs and Dunleavy, 1975 and Scalbert, 1991). The mechanisms thought to be responsible for phenolic toxicity to microorganisms include enzyme inhibition by the oxidized compounds, possibly through reaction with sulfhydryl groups or through more nonspecific interactions with the proteins (Mason and Wasserman, 1987).

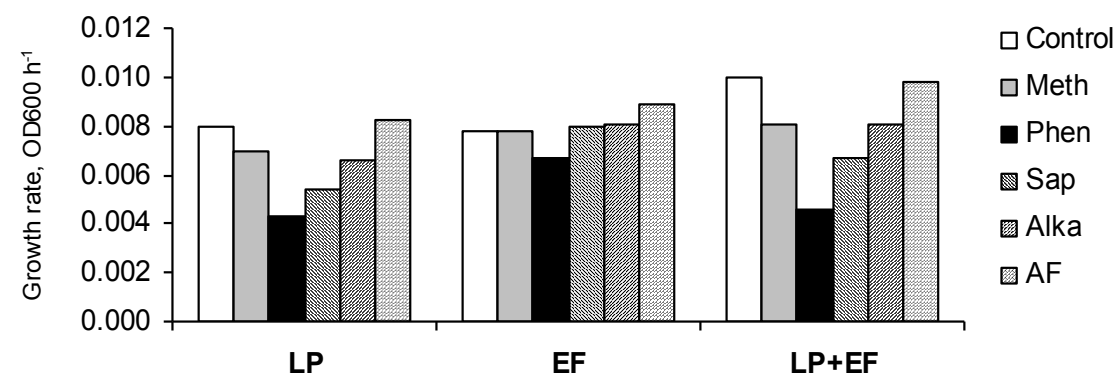

Figure 1. Growth rate $\left(O D_{600} h^{-1}\right)$ of LAIB $^{1}$ and there mixture in sheep under different treatment by anti-nutritional factors extracted from Acacia saligna leaves

${ }^{1}$ LP: Lactobacillus planterum, EF: Enterococcus faecium, LP + EF: Lactobacillus planterum + Enterococcus faecium (1:1).

Meth: Methanolic extract; Phen: Phenolic components; Sap: Saponins; Alka: Alkaloids; AF: Aqueous fraction. Rate of bacterial growth was calculated by the slope of lactic acid production curve during the different times of incubations.

Lower $(\mathrm{P}<0.05)$ bacterial growth rate (Figure 1) was observed with the effect of phenolic components on all LAIB in comparison to control. It was suggested that 
phenolic components had a capacity to precipitate bacterial enzyme and bind to cell membrane which led to reduce the bacteria growth rate (Brooker et al., 2000 and McSweeney et al., 2001). Changes in bacterial growth (Figure 2) under each one of ANFs during the different incubation times had confirmed the mean values. Bacterial growth of L. planterum and their mixture L. planterum + E. faecium under phenolic components was maintained lower than the growth under other ANFs. E. faecium appeared their resistant to ANFs a long the all times of incubations.

Lactic acid production as the activity product of LAIB under each one of ANFs was also negativity affected (Tables 4 and 5). This occurred could be as a consequence to their effect on bacterial growth. Phenolic components, methanolic extract and alkaloids had a highly inhibitory effect on lactic acid production by $L$. planterum, E. faecium and their mixture of L. planterum + E. faecium, respectively. The mixture of L. planterum + E. faecium increased $(\mathrm{P}<0.001)$ their capacity to lactic acid production under the all ANFs except alkaloids. L. planterum had a highest value than the other bacterial strains. However, phenolic components affect meanly on LAIB by decreasing the lactic acid production by each one of LAIB singly. This effect may be due to their effect on bacterial cell wall and could the direct effect on their modification of the permeability of bacterial cell membrane, which affects negativity on bacterial growth rate (Leinmüller et al., 1991 and Scalbert 1991).
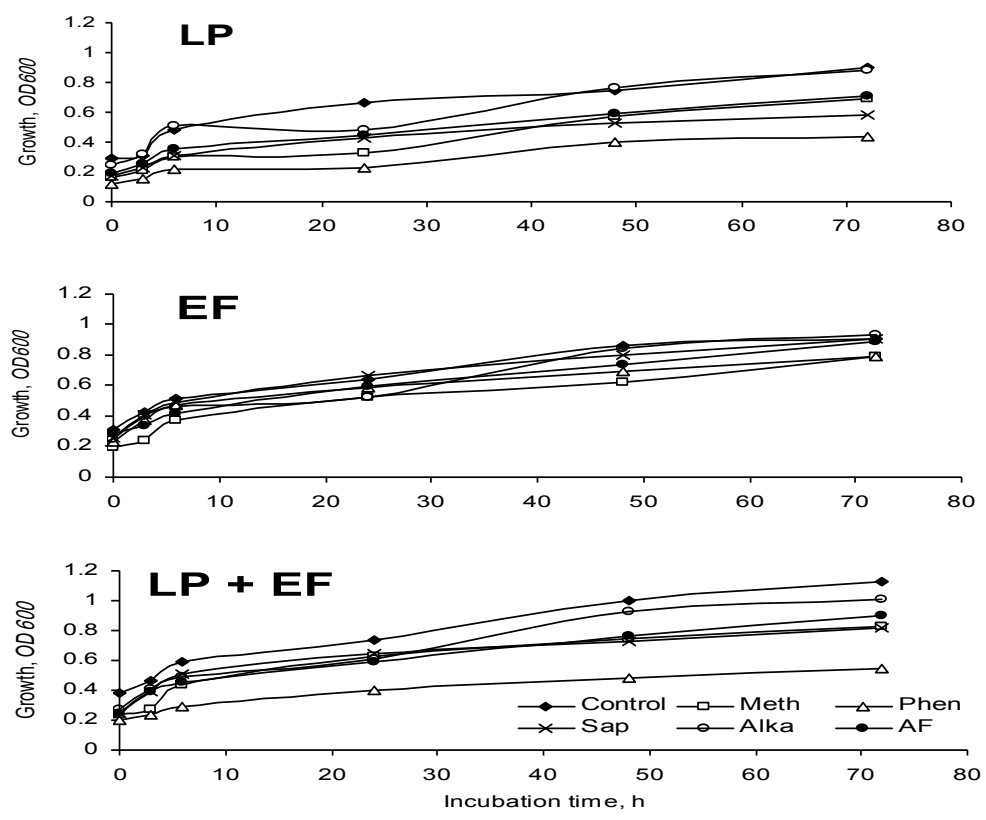

Figure 2. Effect of different anti-nutritional factors extracted from Acacia saligna leaves on bacterial growth $(O D 600)$ of the identified LAIB in sheep $(L$. planterum (LP), E. faecium (EF) and L. planterum + E. faecium (LP+EF) by 1:1) during different times of incubations

Control; Methanolic extract (Meth); Phenolic components (Phen); Saponins (Sap); Alkaloids (Alka); Aqueous fraction (AF). 
Table 4. Effect of different anti-nutritional factors extracted from Acacia saligna leaves on lactic acid production $\left(\mathrm{g} \mathrm{L}^{-1}\right)$ of isolated lactic acid intestinal bacteria in sheep

\begin{tabular}{lccccc}
\hline \multirow{2}{*}{ Treatment } & \multicolumn{3}{c}{ Bacterial strain } & & \multirow{2}{*}{ Sig } \\
\cline { 2 - 4 } & $\mathbf{L P}$ & $\mathbf{E F}$ & $\mathbf{L P}+\mathbf{E F}$ & Sed $_{\text {B(A) }}$ & Sig \\
\hline Control & $2.59^{\mathrm{bA}}$ & $2.39^{\mathrm{cA}}$ & $2.87^{\mathrm{aA}}$ & 0.064 & $* * *$ \\
Methanolic extract & $1.72^{\mathrm{bD}}$ & $1.67^{\mathrm{bD}}$ & $2.33^{\mathrm{aC}}$ & 0.034 & $* * *$ \\
Phenolic components & $1.63^{\mathrm{cE}}$ & $1.88^{\mathrm{bC}}$ & $2.06^{\mathrm{aD}}$ & 0.023 & $* * *$ \\
Saponins & $1.79^{\mathrm{cD}}$ & $2.17^{\mathrm{bB}}$ & $2.53^{\mathrm{aB}}$ & 0.046 & $* * *$ \\
Alkaloids & $2.42^{\mathrm{aB}}$ & $1.93^{\mathrm{bC}}$ & $1.48^{\mathrm{cE}}$ & 0.060 & $* * *$ \\
Aqueous fraction & $1.95^{\mathrm{cC}}$ & $2.26^{\mathrm{bAB}}$ & $2.54^{\mathrm{aB}}$ & 0.047 & $* * *$ \\
Sed & 0.044 & 0.062 & 0.032 & & \\
Sig & $* * *$ & $* * *$ & $* * *$ & &
\end{tabular}

LP: Lactobacillus planterum, EF: Enterococcus faecium, LP + EF: Lactobacillus planterum + Enterococcus faecium (1:1).

$\mathrm{A}, \mathrm{B}, \mathrm{C}, \mathrm{D}$ means in the same column with different superscripts are significantly different between treatments within each one of lactic acid intestinal bacteria strains. $* * *(\mathrm{P}<0.001)$ NS: not significance Sig.: Level of significant.

a,b means in the same row with different superscripts are significantly different between lactic acid intestinal bacteria within each one of treatments.

$\operatorname{Sed}_{\mathrm{A}(\mathrm{B})}$ : stander error of the differences between treatments within each lactic acid intestinal bacteria strains.

$\operatorname{Sed}_{B(A)}$ : stander error of the differences between lactic acid intestinal bacteria strains within each treatments.

Table 5. Negatively effect $(\%)$ of different anti-nutritional factors extracted from Acacia saligna leaves on lactic acid production $\left(\mathrm{g} \mathrm{L}^{-1}\right)$ of isolated lactic acid intestinal bacteria in sheep

\begin{tabular}{lccc}
\hline & \multicolumn{3}{c}{ Bacterial strain } \\
\cline { 2 - 4 } Treatment & LP & EF & LP + EF \\
\hline Control & 0.00 & 0.00 & 0.00 \\
Methanolic extract & 33.59 & 30.13 & 18.82 \\
Phenolic components & 37.07 & 21.34 & 28.22 \\
Saponins & 30.89 & 9.21 & 11.85 \\
Alkaloids & 6.56 & 19.25 & 48.43 \\
Aqueous fraction & 24.71 & 5.44 & 11.50 \\
\hline
\end{tabular}

LP: Lactobacillus planterum, EF: Enterococcus faecium, LP + EF: Lactobacillus planterum + Enterococcus faecium (1:1).

Mixing of LAIB in this study could have a capacity to tolerate the negative effect of the ANFs extracted from A. saligna leaves by increasing their production of lactic acid in order to reduce the $\mathrm{pH}$ value of the intestine media. Lower $\mathrm{pH}$ value of intestine probably reduces the capacity of ANFs (specially tannins as a type of phenolic components) to bind with bacterial enzyme or protein membrane of cell wall and increase the bacterial activity (Bae et al., 1993 and McSweeney et al., 2001). Kaitho et al., (1998) reported that the suitable $\mathrm{pH}$ value for formation complex 
between tannins and protein was ranged between 5 and 7. Lower $\mathrm{pH}$ value of intestine to 3.5 had a capacity to disassociate the complex between tannins and protein of bacterial cell wall (Jones and Mangan 1977).

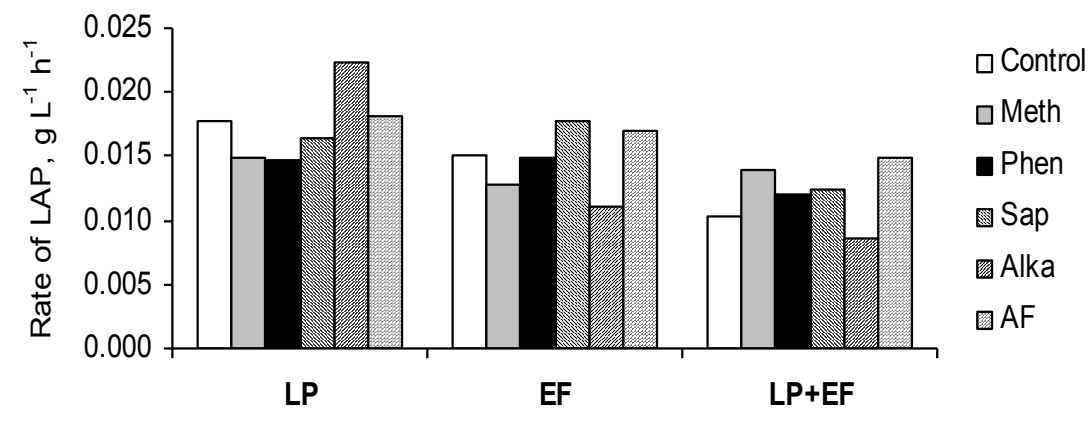

Figure 3. Rate of lactic acid production (LAP, $\mathrm{g} \mathrm{L}^{-1} \mathrm{~h}^{-1}$ ) of $\mathrm{LAIB}^{1}$ and their mixture in sheep under different treatment by anti-nutritional factors extracted from Acacia saligna leaves

${ }^{1}$ LP: Lactobacillus planterum, EF: Enterococcus faecium, LP + EF: Lactobacillus planterum + Enterococcus faecium (1:1), Meth: Methanolic extract; Phen: Phenolic components; Sap: Saponins; Alka: Alkaloids; AF: Aqueous fraction.

Rate of lactic acid was calculated by the slope of lactic acid production curve during the different times of incubations.

Rate of lactic acid production (Figure 3) by L. planterum was significantly $(\mathrm{P}<0.001)$ higher under alkaloids than control. E. faecium increased their production from lactic acid under saponins and Aqueous fraction. This effect may be due to the capacity of some LAIB to degrade some ANF. For example, L. planterum had a capacity to degrade alkaloids in leaves than other ANFs, but E. faecium degrade saponins and lactine. This may be due to the different characterization between intestinal bacteria in degrading ANFs. The mixture of LAIB increased lactic acid production under all ANF than control, which reflect the synergism between LAIB to degrade all ANFs in $A$. saligna leaves.

The behavior of lactic acid production by different LAIB strain under ANFs is showed in Figure 4. Lower production was by L. planterum under phenolic components than other ANFs. Alkaloids showed a highly inhibitory effect on lactic acid production by the mixture of L. planterum + E. faecium than othe ANFs, but in general, mixing of LAIB increased lactic acid concentration in medium than each one of bacterial strain singly. Negative effect of ANF on biomass production (Tables 6 and 7) had the same trend of their effect on bacterial growth and lactic acid production

L. planterum increased number of resistant colonies (Table 8) under phenolics components, although it had a highly negative effect on $L$. planterum growth, lactic acid, and biomass production. This meaning that L. planterum increased number of mutant cells to reduce the negative effect of phenolic components (Nelson et al., 1998; Brooker et al., 2000; McSweeney et al., 2001 and Salem, 2002). Number of 
resistant colonies of E. faecium was increased under aqueous fraction. This number was also increased at the case of mixing L. planterum + E. faecium under the treatment with saponins.

An adversely relationships (Figure 5) was observed between toxicity (inhibition zone area) and bacterial growth and lactic acid by all LAIB and their mixture.
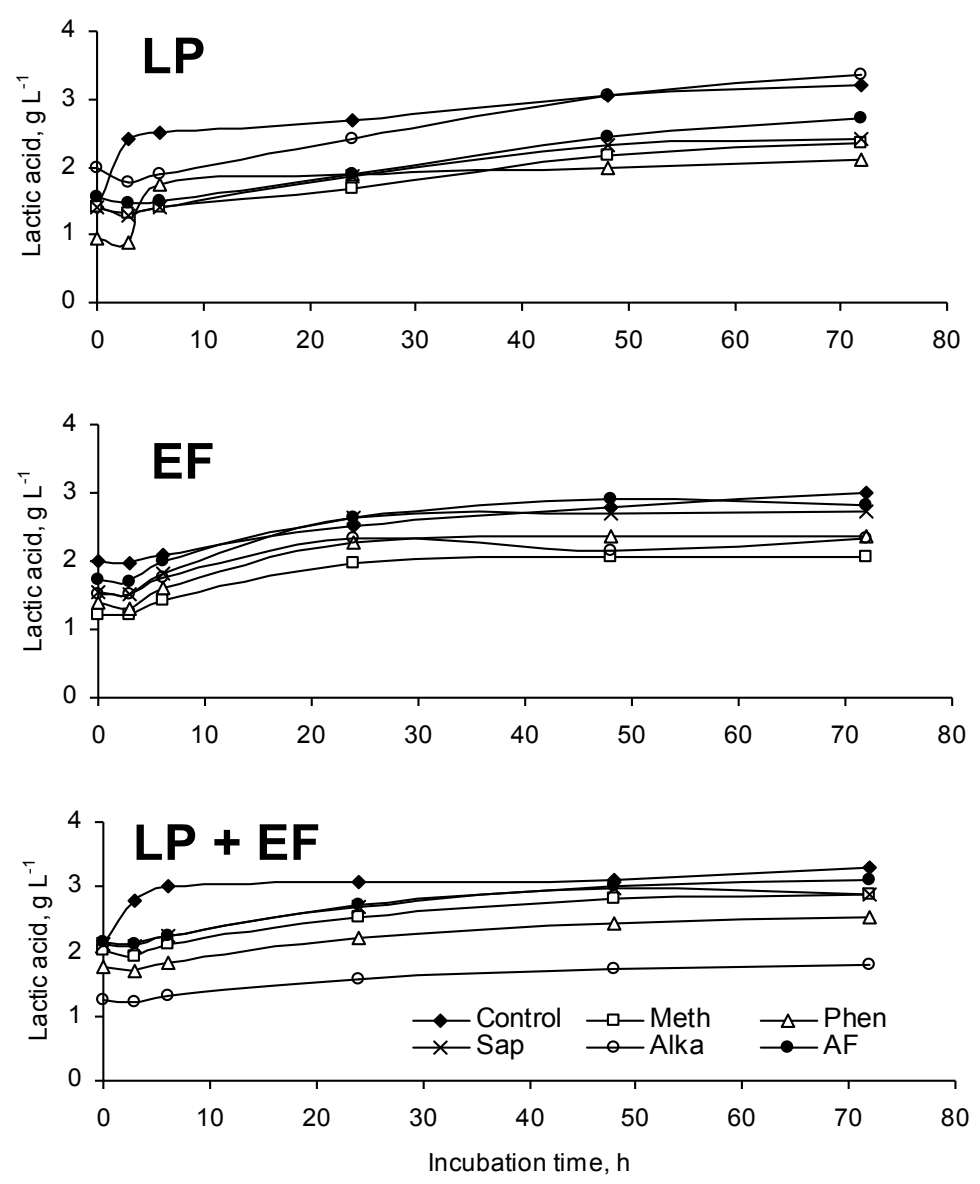

Figure 4. Effect of different anti-nutritional factors extracted from Acacia saligna leaves on on lactic acid production $\left(\mathrm{g} \mathrm{L}^{-1}\right)$ of the identified LAIB in sheep (L. planterum (LP), E. faecium (EF) and L. planterum + E. faecium $(\mathrm{LP}+\mathrm{EF})$ by 1:1) during different times of incubations

Control; Methanolic extract (Meth); Phenolic components (Phen); Saponins (Sap); Alkaloids (Alka); Aqueous fraction (AF). 
Table 6. Effect of different anti-nutritional factors extracted from Acacia saligna leaves on biomass production $\left(\mathrm{g} \mathrm{L}^{-1}\right)$ of isolated lactic acid intestinal bacteria in sheep

\begin{tabular}{|c|c|c|c|c|c|}
\hline \multirow[b]{2}{*}{ Treatment } & \multicolumn{3}{|c|}{ Bacterial strain } & \multirow[b]{2}{*}{$\operatorname{Sed}_{B(A)}$} & \multirow[b]{2}{*}{ Sig } \\
\hline & LP & EF & $\mathbf{L P}+\mathbf{E F}$ & & \\
\hline Control & $4.64^{\mathrm{bA}}$ & $3.61^{\mathrm{cA}}$ & $5.61^{\mathrm{aA}}$ & 0.086 & $* * *$ \\
\hline Methanolic extract & $3.10^{\mathrm{bC}}$ & $2.33^{\mathrm{cD}}$ & $4.57^{\mathrm{aB}}$ & 0.045 & $* * *$ \\
\hline Phenolic components & $2.22^{\mathrm{cD}}$ & $2.64^{\mathrm{bC}}$ & $3.97^{\mathrm{aC}}$ & 0.016 & $* * *$ \\
\hline Saponins & $3.22^{\mathrm{bC}}$ & $2.96^{\mathrm{cB}}$ & $4.35^{\mathrm{aB}}$ & 0.096 & $* * *$ \\
\hline Alkaloids & $4.63^{\mathrm{bA}}$ & $2.79^{\mathrm{cC}}$ & $5.42^{\mathrm{aA}}$ & 0.182 & $* * *$ \\
\hline Aqueous fraction & $3.62^{\mathrm{bB}}$ & $3.25^{\mathrm{cA}}$ & $4.62^{\mathrm{aB}}$ & 0.100 & $* * *$ \\
\hline $\operatorname{Sed}_{\mathrm{A}(\mathrm{B})}$ & 0.087 & 0.077 & 0.132 & & \\
\hline Sig & $* * *$ & $* * *$ & $* * *$ & & \\
\hline
\end{tabular}

LP: Lactobacillus planterum, EF: Enterococcus faecium, LP + EF: Lactobacillus planterum + Enterococcus faecium (1:1).

$\mathrm{A}, \mathrm{B}, \mathrm{C}, \mathrm{D}$ means in the same column with different superscripts are significantly different between treatments within each one of lactic acid intestinal bacteria strains.

$* * *(\mathrm{P}<0.001) \quad$ NS: not significance Sig.: Level of significant.

${ }^{\mathrm{a}, \mathrm{b}}$ means in the same row with different superscripts are significantly different between lactic acid intestinal bacteria within each one of treatments.

$\mathrm{Sed}_{\mathrm{A}(\mathrm{B})}$ : stander error of the differences between treatments within each lactic acid intestinal bacteria strains.

$\operatorname{Sed}_{B(A)}$ : stander error of the differences between lactic acid intestinal bacteria strains within each treatments.

Table 7. Inhibitory effect (\%) of different anti-nutritional factors extracted from Acacia saligna leaves on biomass production of isolated lactic acid intestinal bacteria in sheep

\begin{tabular}{lccc}
\hline & \multicolumn{3}{c}{ Bacterial strain } \\
\cline { 2 - 4 } Treatment & LP & EF & LP + EF \\
\hline Control & 0.00 & 0.00 & 0.00 \\
Methanolic extract & 33.19 & 35.46 & 18.54 \\
Phenolic components & 52.16 & 26.87 & 29.23 \\
Saponins & 30.60 & 18.01 & 22.46 \\
Alkaloids & 0.22 & 22.71 & 3.39 \\
Aqueous fraction & 21.98 & 9.97 & 17.65 \\
\hline
\end{tabular}

LP: Lactobacillus planterum, EF: Enterococcus faecium, LP + EF: Lactobacillus planterum + Enterococcus faecium (1:1). 

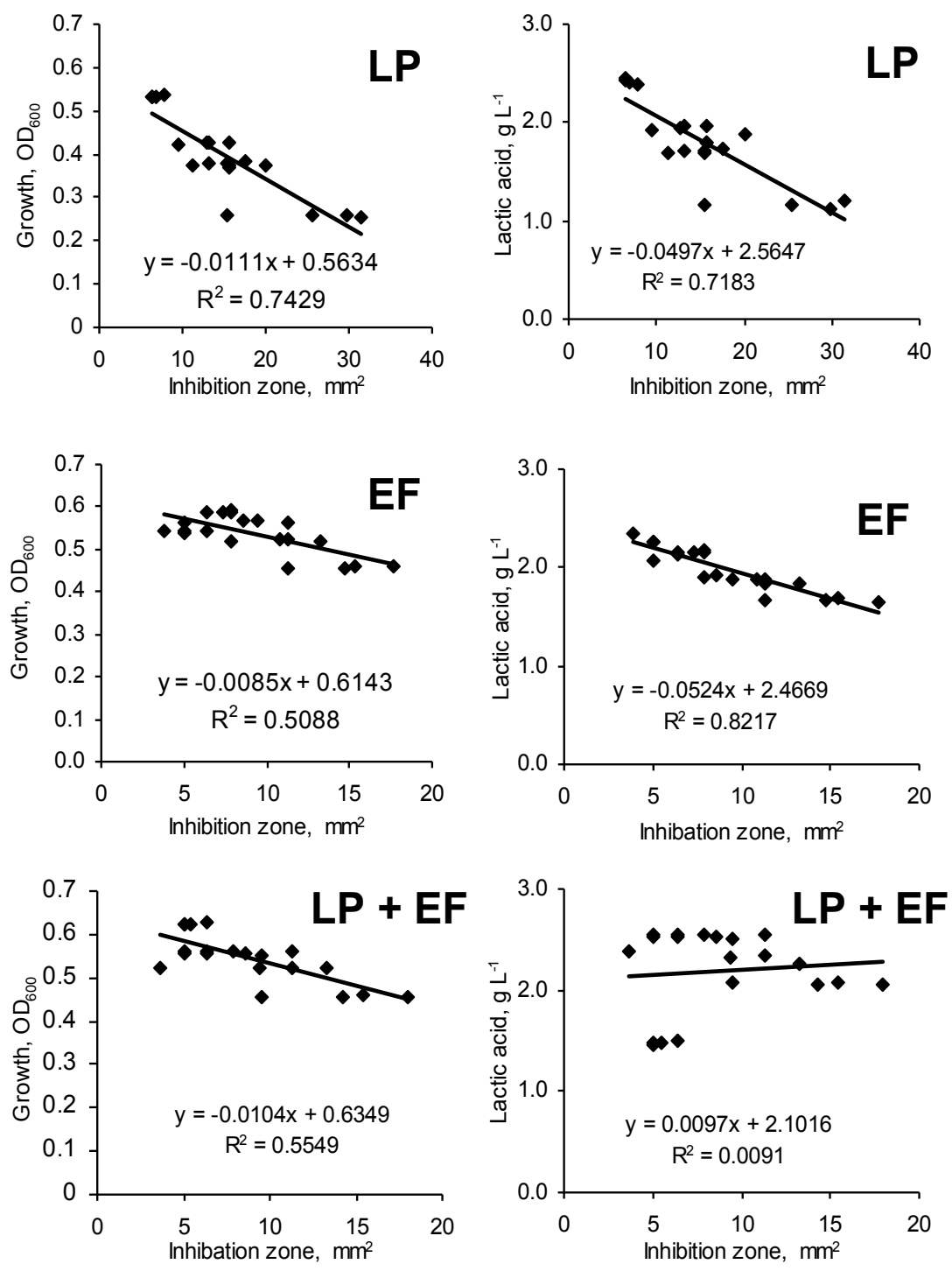

Figure 5. Relationship between toxicity (the area of formulated inhibition zone) of ANFs and bacterial growth and lactic acid production in each one of LAIB strain 
Table 8. Effect of different anti-nutritional factors extracted from Acacia saligna leaves on the counts of resistant colonies ${ }^{\#}$ of isolated lactic acid intestinal bacteria in sheep

\begin{tabular}{|c|c|c|c|c|c|}
\hline \multirow[b]{2}{*}{ Treatment } & \multicolumn{3}{|c|}{ Bacterial strain } & \multirow[b]{2}{*}{$\operatorname{Sed}_{B(A)}$} & \multirow[b]{2}{*}{ Sig } \\
\hline & LP & EF & $\mathbf{L P}+\mathbf{E F}$ & & \\
\hline Methanolic extract & $1.67^{\mathrm{cC}}$ & $8.33^{\mathrm{bD}}$ & $52.00^{\mathrm{aA}}$ & 1.610 & $* * *$ \\
\hline Phenolic components & $19.67^{\mathrm{A}}$ & $15.67^{\mathrm{C}}$ & $19.67^{\mathrm{C}}$ & 2.160 & NS \\
\hline Saponins & $6.33^{\mathrm{cB}}$ & $32.33^{\mathrm{bB}}$ & $39.67^{\mathrm{aB}}$ & 2.160 & $* * *$ \\
\hline Alkaloids & $1.67^{\mathrm{cC}}$ & $9.00^{\mathrm{bD}}$ & $38.00^{\mathrm{aB}}$ & 2.018 & $* * *$ \\
\hline Aqueous fraction & $1.00^{\mathrm{cC}}$ & $41.67^{\mathrm{aA}}$ & $14.67^{\mathrm{bC}}$ & 2.091 & $* * *$ \\
\hline $\operatorname{Sed}_{\mathrm{A}(\mathrm{B})}$ & 1.726 & 1.874 & 2.394 & & \\
\hline $\mathrm{Sig}$ & $* * *$ & $* * *$ & $* * *$ & & \\
\hline
\end{tabular}

LP: Lactobacillus planterum, EF: Enterococcus faecium, LP + EF: Lactobacillus planterum + Enterococcus faecium (1:1). \#: Resistant colonies, which appeared in the inhibition zone area, were picked up and calculated under the stereomicroscope. All colonies were found at the area of the inhibition zone that was considered as mutant colonies.

$\mathrm{A}, \mathrm{B}, \mathrm{C}, \mathrm{D} ;$; means in the same column with different superscripts are significantly different between treatments within each one of lactic acid intestinal bacteria strains, $* * *=(\mathrm{P}<0.001)$, Sig.: Level of significant, NS: not significance.

a,b; means in the same row with different superscripts are significantly different between lactic acid intestinal bacteria within each one of treatments.

$\operatorname{Sed}_{\mathrm{A}(\mathrm{B})}$ : stander error of the differences between treatments within each lactic acid intestinal bacteria strains.

$\operatorname{Sed}_{B(A)}$ : stander error of the differences between lactic acid intestinal bacteria strains within each treatments.

\section{CONCLUSIONS}

1- Phenolic components are the major group of ANFs in Acacia saligna leaves, which had more inhibitory effect than other ANFs on LAIB activity.

2- Lactobacilli sp. had a higher susceptibility than Enterococci $s p$. to the ANFs.

3- Mixing LAIB had increased their tolerance to the all ANFs.

\section{REFERENCES}

Ahmad, V.U., S. Perveen and S. Bano, 1990. Saponins from the leaves of Guaiacum officinale. Phytochemistry, 29:3287-3290.

Ahn, J. H., B. M. Robertson, R. Elliot and R. C. Gutteridge, 1989. Quality assessment of tropical browse legumes: tannin content and protein degradation. Animal Feed Science and Technology 27: 147-56.

Araambewela, L. S. R. and T. Ranatunge, 1991. Indole alkaloids from Tabernaemontana divaricata. Phytochemistry 30:1740-1741.

Ausubel, F., R. Brent, R. E. Kingston, D. D. Moore, J. G. Seidman, J. A. Smith and K. Struhl, 1995. Short protocols in molecular biology. $3^{\text {ed }}$ ed. John Wiley and Sons, Inc, New York, N.Y.

Avorn, J. 1996. The effect of cranberry juice on the presence of bacteria and white blood cells in the urine of elderly women. What is the role of bacterial adhesion? Adv. Exp. Med. Biol. 408:185-186. 
Bae, H. D., T. A. McAllister, L. J. Yanke, K. J. Cheng and A. D. Muir, 1993. Effect of condensed tannins on enduglucanase activity and filter paper digestion by Fibrobacter succinogene. 585. Applied and Environmental Microbiology 59: 2132- 3138.

Balls, A. K., W. S. Hale and T. H. Harris, 1942. A crystalline protein obtained from a lipoprotein of wheat flour. Cereal Chemistry 19:279-288.

Berg, R. D., 1996. The indigenous gastrointestinal microflora. Trends Microbiology. 4:430-435.

Berkada, B. 1978. Preliminary report on warfarin for the treatment of herpes simplex. J. Irish Coll. Phys. Surg. 22(Suppl.):56.

Brooker, J.D., L. A. O’Donovan, I. Skene and G. Sellick, 2000. Mechanisms of tannin resistance and detoxification in the rumen. In: Tannins in Livestock and Human Nutrition. Brooker, J. D. (Ed.), pp. 117-122. ACIAR Proceeding No. 92, Australia.

Cowan, M.M., 1999. Plant Products as Antimicrobial Agents. Clinical Microbiology Reviews 12: 564-582.

De Man, J. C. D. E., M. Rogosa and M. E. Sharpe, 1960. A medium for Lactobacilli. Journal Applied of Bacteriology 23:130-138.

Freiburghaus, F., R. Kaminsky, M. H. H. Nkunya and R. Brun, 1996. Evaluation of African medicinal plants for their in vitro trypanocidal activity. Journal of Ethnopharmacology 55:1-11.

Garvie, E.I., 1986. Genus Leuconostoc van Tieghem, 1878, 198 ${ }^{\mathrm{AL}}$, emend. Mut. Char. Hucker and peterson 1930, p. 1071-1075. In: P.A.Sneath, N.S. Mair, M.E.Shatpe and J.G Holt (eds.), Bergeys Manual of Systematic Bacteriology, Vol.2, the Williams and Wilkins Co., Baltimore.

Geissman, T.A., 1963. Flavonoid compounds, tannins, lignins and related compounds, p. 265. In M. Florkin and E. H. Stotz (ed.), Pyrrole pigments, isoprenoid compounds and phenolic plant constituents, vol. 9. Elsevier, New York, N.Y.

Hardie, J.M., 1986. Genus Streptococcus Rosenbach 1884, 22 ${ }^{\mathrm{AL}}$, P.1043-1071. In: P.A.Sneath, N.S. Mair, M.E.Shatpe and J.G Holt (eds.), Bergeys Manual of Systematic Bacteriology, Vol.2, the Williams and Wilkins Co., Baltimore, USA.

Hopp, K. H., L. V. Cunningham, M. C. Bromel, L. J. Schermeister and S. K. Wahba Khalil, 1976. In vitro anti-trypanosomal activity of certain alkaloids against Trypanosoma lewisi. Lloydia 39:375-377.

Hussein, G., N. Nakamura, M. R. Meselhy and M. Hattori, 1999. Phenolics from Maytenus senegalensis. Phytochemistry 50:689-694.

Jones, W.T. and J. L. Mangan, 1977. Complexes of the condensed tannins of Sainfoin (Onobrychia viciifolia Scop.) with fraction I leaf protein and with submaxillary mucoprotein and their reversal by polyethylene glycols and $\mathrm{pH}$. Journal of the Science of Food and Agriculture 28:126-136.

Kaitho, R. J., N. N. Umunna, I. V. Nsahlai, S.Tamminga and J. V. Van Bruchem, 1998. Relationships between preference, rumen degradability, gas production and chemical composition of browses. Agroforestry Systems 39:129-144.

Kandler, O. and N. Weiss, 1986. Genus Lactobacillus Beijerinck 1901, 212 ${ }^{\mathrm{AL}}$, P. 1209-1234. In: P.A.Sneath, N.S. Mair, M.E.Shatpe and J.G Holt (eds.), Bergeys 
Manual of Systematic Bacteriology, Vol.2, the Williams and Wilkins Co., Baltimore.

Kibon, A. and E.R. Ørskov, 1993. The use of degradation characteristics of browse plants to predict intake and digestibility by goats. Animal Production 57(2): 247251.

Leinmüller, E., H. Steingass and K. H. Menke, 1991. Tannins in ruminants feedstuffs In: Biannual Collection of Recent German Contributions Concerning Development through Animal Research. Institute for scientific cooperation (Ed.), pp. 33:9-62. Germany.

Lu, C.D., and N.A. Jorgensen, 1987. Alfalfa saponins affect site and extent of nutrient digestion in ruminants. J. Nutrition, Phytochemstry 117:919.

Martinez, M. J., J. Betancourt, N. Alonso-Gonzalez, and A. Jauregui, 1996. Screening of some Cuban medicinal plants for antimicrobial activity. Journal of Ethno pharmacology. 52:171-174.

Mason, T. L., and B. P. Wasserman, 1987. Inactivation of red beet betaglucan synthesis by native and oxidized phenolic compounds. Phytochemistry 26:21972202.

McDevitt, J. T., D. M. Schneider, S. K. Katiyar, and T. D. Edlind, 1996. Berberine: a candidate for the treatment of diarrhea in AIDS patients, abstr. 175. In Program and Abstracts of the 36th Interscience Conference on Antimicrobial Agents and Chemotherapy. American Society for Microbiology, Washington, D.C.

McSweeney, C. S., B. Palmer, R. Bunch, and D. O. Krause, 2001. Effect of the tropical forage Calliandra on microbial protein synthesis and ecology in the rumen. Applied and Environmental Microbiology 90:78-88.

Moore, W. E. C., and L. V. Holdeman, 1974. Human fecal flora: the normal flora of 20 Japanese-Hawaiians. Applied Microbiology 27:961-979.

Nelson, K. E., M. L. Thonney, T. K. Woolston, S. H. Zinder, and A. N. Pell, 1998. Phenotypic and phylogentic characterization of ruminal-tolerant bacteria. Applied and Environmental Microbiology 64:3824-3830.

Phillipson, J. D. and M. J. O'Neill, 1987. New leads to the treatment of protozoal infections based on natural product molecules. Acta Pharm. Nord. 1:131-144.

Pot, R., P. Vandamme and K. Kersters, 1994. Analysis of electrophoretic wholeorganism protein fingerprints. P. 493-521, In: Goodfellow, and A.G. O’Dunnel (eds.) chemical Methods in Prokaryotic Systematic. J. Wiley and Sons, Inc., Chichester, England.

Salem, A.Z.M., 2002. Parotid saliva production and composition, feeding behavior, rumen fermentation, digestibility, and plasmatic parameters in sheep and goats: Evolution of the response to the condensed tannins of quebracho in the diet. Ph.D. Thesis. University of Leon, Spain.

Salem, A. Z. M., M. M. El-Adawy, M. Z. M. Salem and A. A. Hassan, 2004. Effect of probiotics feed as additives on the activity of isolated and characterized lactic acid intestinal bacteria to inhibit Escherichia coli-10 in sheep. Egyptian Journal of Nutrition and Feeds. (accepted and under publication).

SAS, 1993. SAS/STAT User's Guide. Version 6,4 ${ }^{\text {th }}$ ed). SAS Inst., Cary, NC.

Savage, D. C. 1977. Microbial ecology of the gastrointestinal tract. Annu. Rev. Microbiol. 31:107-133

Savage, D.C. 1989. Gastrointestinal microflora in mammalien nutrition. Annu. Rev. Nutr. 6:155-78. 
Scalbert, A., 1991. Antimicrobial properties of tannins. Photochemistry 30: 38753883.

Sharpe, M.E., 1979. Identification of the lactic acid bacteria. P. 233-259. In: F.A. Skinner and D.W. Lovelock (eds.), Identification Methods for Microbiologists. $2^{\text {nd }}$, Academic Press, London.

Sharon, N., and I. Ofek, 1986. Mannose specific bacterial surface lectins, p. 55-82. In D. Mirelman (ed.), Microbial lectins and agglutinins. John Wiley \& Sons, Inc., New York, N.Y. Ethnopharmacology 50:97-102.

Schultes, R.E., 1978. The kingdom of plants, In Medicines from the Earth. W. A. R. Thomson (ed.), p. 208. McGraw-Hill Book Co., New York, N.Y.

Steel, R.G.D. and J. H. Torrie, 1980. Principles and Procedures of Statistics. $2^{\text {nd }}$ ed. McGraw-Hill International.

Taylor, K.A.C.C., 1996. A simple colorimetric assay for muramic acid and lactic acid. Applied Biochemistry and Biotechnology 56:49-58.

Terzaghi, B.E. and W.E. Sandine, 1975. Improved medium for lactic streptococci and their bacteriophages. Applied Microbiology 29:807-813.

Terras, F.R.G., H.M.E. Schoofs, H. M. E. Thevissen, R. W. Osborn, J. Vanderleyden, B. P. A. Cammue and W. F. Broekaert, 1993. Synergistic enhancement of the antifungal activity of wheat and barley thionins by radish and oilseed rape $2 \mathrm{~S}$ albumins and by barley trypsin inhibitors. Plant Physiology 103:1311-1319.

Thornberry, H.H., 1950. A paper-disk methods for the quantitative evaluation of fungicides and bactericides. Phytopathology 40:419-420.

Urs, N.V.R.R. and J.M. Dunleavy, 1975. Enhancement of the bactericidal activity of a peroxidase system by phenolic compounds (Xanthomonas phaseoli var. sojensis, soybeans). Phytopathology 65:686-690.

Zhang, Y. and K. Lewis, 1997. Fabatins: new antimicrobial plant peptides. FEMS Microbiol. Lett. 149:59-64. 
التأثير التثبطي لبعض العوامل المضادة للتفذية anti-nutritional factors المستخلصة من أوراق ألاكاسيا Acacia saligna على نشاط بكتيريا الأمعاء في الأغنام

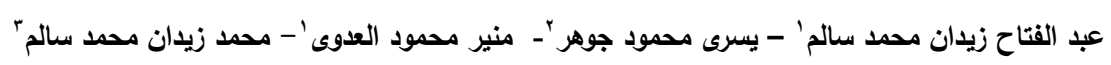

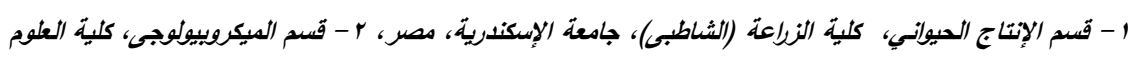

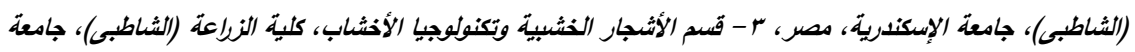
الإسكندرية، مصر،

أجريت هذه الدراسة بهدف تقيم الثأثير التثبطي لبعض العوامل المضادة للتغذية anti-nutritional Acacia saligna العلى نشاط بكتبريا الأمعاء المنتجة لحمض اللاكتيك. تم عزل و تعريف سلالتين من بكتيريا الأمعاء المنتجة لحمض اللاكتيك ماكل من أمعاء الأغنام

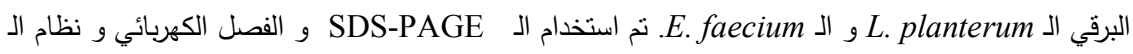

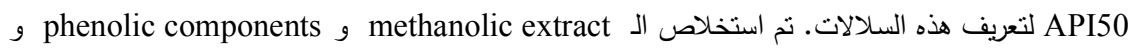

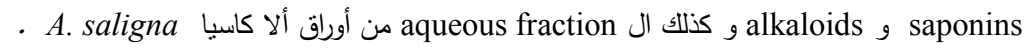
تم تقيم التأثير التثبيطي لكل نوع من ال ANFs عند مستوى 20000 ppm على نثاط البكتيريا

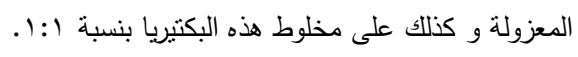

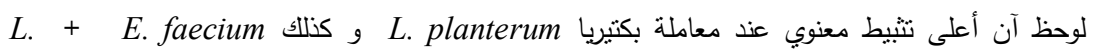
عند استخدام ال E. faecium بواسطة ال planterum

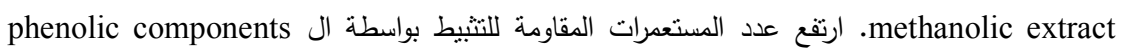

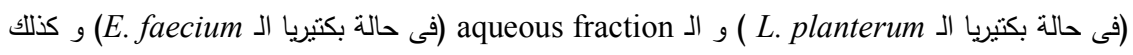

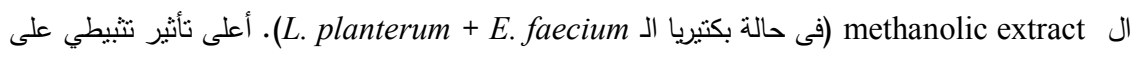

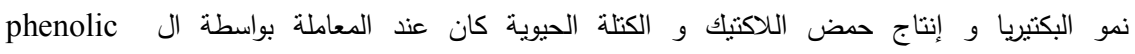
لبكتبريا ال L. planterum components

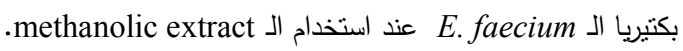

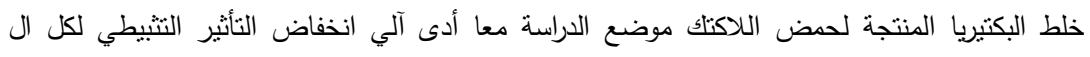

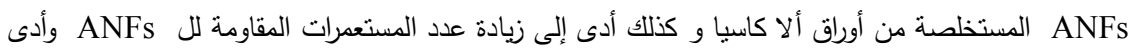

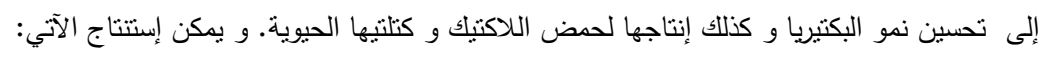

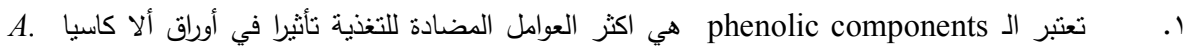
saligna

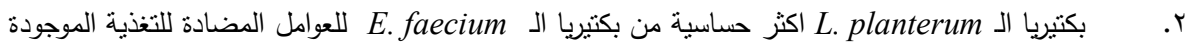
في أوراق ألا كاسيا. r. خلط البكتيريا أدى إلى زيادة مقاومتها للعوامل المضادة للتغذية. 